\title{
The Economic Value of Rapid AST in Reducing Length of Stay of Septic Patients
}

\author{
Karan Bains ${ }^{1 *}$, Rajkumar S Pammal ${ }^{2}$, and Adam E Block ${ }^{3}$ \\ ${ }^{1}$ Weil Cornell Medical School, USA \\ ${ }^{2}$ New York Medical College School of Medicine, USA \\ ${ }^{3}$ Assistant Professor of Public Health at New York Medical College-School of Health Sciences and Practice, USA
}

*Corresponding author: Karan Bains, Weil Cornell Medical School, USA.

Received Date: August 7, 2020

Published Date: August 14, 2020

\begin{abstract}
To construct an economic model to estimate the potential length-of-stay cost savings for hospitals which replace conventional antibiotic susceptibility testing (AST) with rapid AST for the sepsis patient population. We used a wide range of academic studies from the medical and economics literature. Relevant studies were identified and weighted based on study methodological rigor, year of publication and geographic proximity of study population. Each flagged study was read in its entirety and screened for relevant data on inputs to the economic model. Studies which included relevant estimates were read again by two authors to confirm the correct estimate. Each component of the model was compiled from a comprehensive literature search identifying key studies in the field and then combining individual estimates from these studies into a weighted average. Implementation of rapid AST in the sepsis patient population can lead to over $\$ 1,600$ of savings per sepsis case, or $7.3 \%$ of total average admission costs, solely in savings from improved length-of-stay (LOS). When scaled to the hospital level, this represents $\$ 5.65$ million saved per 100,000 total hospital admissions. The magnitude of potential savings suggests that replacing conventional AST with rapid AST could provide a high return on investment for hospital systems.
\end{abstract}

Keywords: Rapid AST; Sepsis; Post-surgical infection; Blood cultures; Length of stay

\section{Introduction}

Although sepsis is not as commonly mentioned in popular media as other deadly conditions, it is the tenth leading cause of death in the United States [1] and responsible for over $55 \%$ of hospital inpatient deaths [2]. Mortality from sepsis is nearly $13 \%$ overall but increases with severity and reaches above 34\% in septic shock cases [3]. Moreover, sepsis cases comprise a larger portion of hospital patient volume than acute myocardial infarctions [4], and sepsis incidence continues to increase by $13 \%$ annually [5].

When patients are first seen in the hospital, standard sepsis protocol indicates they should receive blood cultures, broad- spectrum antibiotics, and lactate measurements within one hour, as well as vasopressors and/or crystalloid under certain clinical scenarios [6]. In fact, for every hour a patient does not receive antibiotics their mortality rate increases by $4 \%$; the mortality increase is particularly pronounced after a three-hour threshold, after which sepsis in-hospital mortality is $14 \%$ higher than in patients receiving antibiotics within three hours [7]. So, providers must treat patients immediately, but have known way to definitively know which antibiotics will be effective based on patient symptoms without blood culture results. Therefore, ED physicians and infectious disease specialists begin with broad-spectrum 
antibiotics covering both gram-positive and gram-negative bacteria [8] and tailor regimens based on the suspected source of infection. However, only blood culture results can identify the causative bacteria but still do not provide any in vitro confirmation that antibiotics are working, even if the antibiotic regimen covers the causative bacteria in theory. For such confirmation, clinicians must wait for the antimicrobial susceptibility test (AST) result, which takes another two days or more with conventional methods. Under the current paradigm of clinical care, septic patients are prescribed broad-spectrum antibiotics for a minimum of three days-and often five or more days-before antibiotic susceptibility results are available and antibiotic treatment can be confirmed as appropriate and broad spectrum antibiotics can be safely narrowed [9]. Therefore, providing a faster time-to-result for ASTs could reduce the overall length-of-stay (LOS) for many of these patients.
Rapid AST technology can allow clinicians to determine which antibiotics will treat which infections in a matter of hours instead of days. For example, SeLux Diagnostics can reduce the operational time it takes to evaluate sepsis treatment from three days to one day by providing AST results the same day as bacterial culture results $[10,11]$. Figure 1 shows how this would work in a hospital for a patient arriving at 9am on Monday morning. By reducing the time by two full hospital days, patients who are treated with medications that are not clearing their infection can receive the correct antibiotic two days faster, and some subset of these patients will therefore be discharged earlier as well. SeLux's rapid AST can also provide an expanded number of antibiotics available for testing ("expanded antibiotic menu"), reducing additional delays due to retesting often needed for sepsis cases caused by multi-drug resistant (MDR) organisms $(12,13)$ (Figure 1).

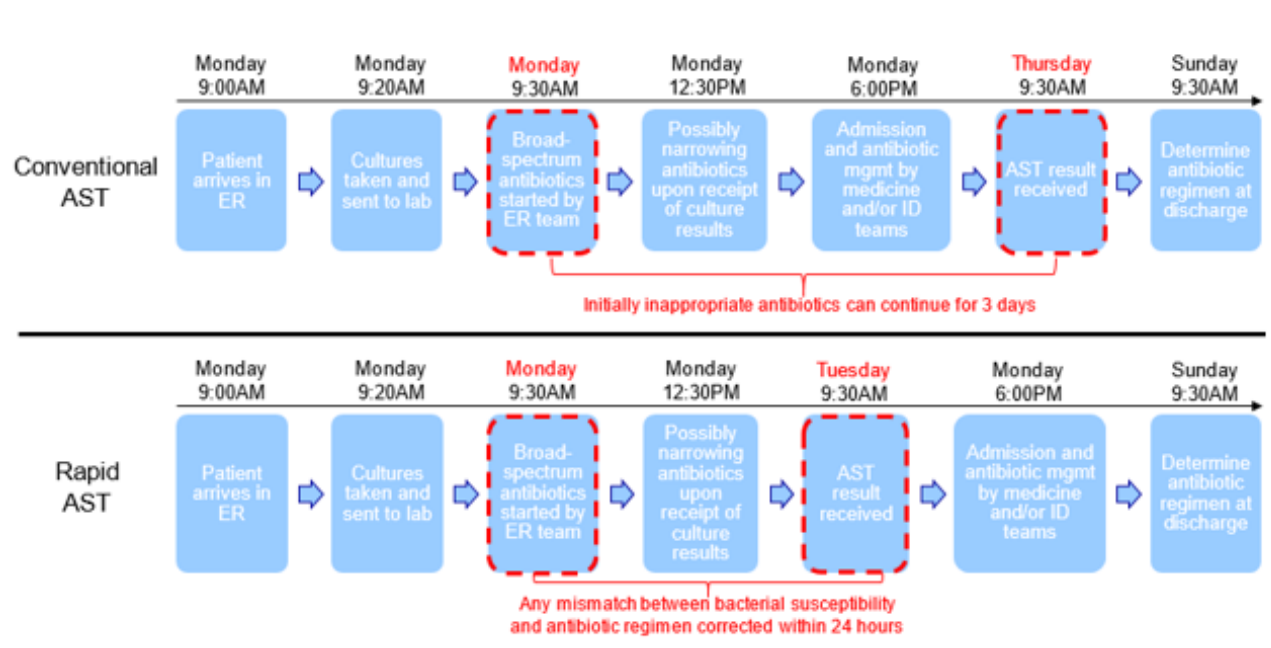

Figure 1: Rapid AST vs. Conventional AST.

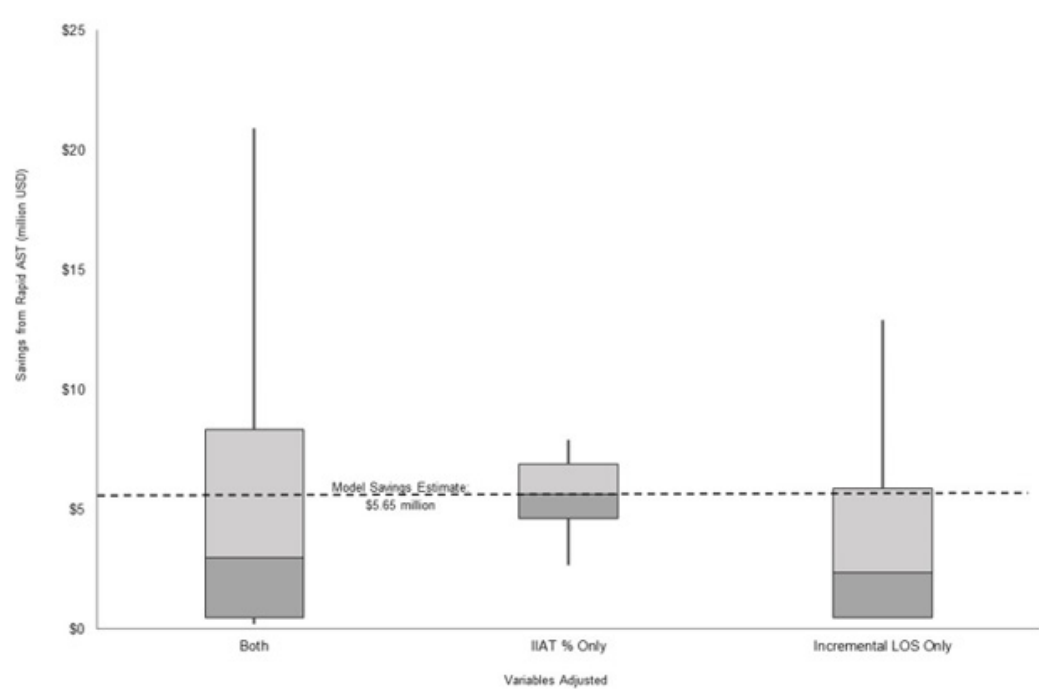

Note: The lower errors bars represent the savings amounts when relevant input variables were at the minimum levels. The dark grey box spans savings from input variables at their $25^{\text {th }}$ percentile to their median, while the light grey box spans savings from input variables at their meridian to their $75^{\text {th }}$ percentile. The top error bars reach the savings when input variables were at maximum levels.

Figure 2: Rapid AST vs. Conventional AST. 
Because hospitals are generally paid a fixed rate (DRG) for each admission regardless of the patient's length-of-stay (LOS) and because many hospital EDs are so busy that when a bed is made available a new patient will fill it, there is an economic value to hospitals to have high throughput (admitting, treating, and discharging patients more quickly) so other sick patients can be admitted. Bed days that are made available are likely to be filled, leading to more hospital revenue. Due to the high fixed-cost nature of running a hospital, the marginal cost for most new visits is relatively small while there is potential for high marginal revenue. In addition, to reduction in LOS for patients, other sources of value from rapid AST include: reduced hospital acquired infections, improved patient value in quality-adjusted life years (QALYs) due to shorter stays, lower expenditures on antibiotics, reduced antibiotic side effects (primarily Clostridium difficile infections), reduced antibiotic-induced acute kidney injury, as well as the positive externality of improved antibiotic stewardship.

All of these benefits are quantifiable for the entire population of infectious disease patients, this study focuses on quantifying the economic value to hospitals from reducing average LOS of sepsis patients due to rapid AST. There is limited recent evidence quantifying the economic value of the reduced time-to-result of rapid AST, although rapid microbial diagnostic tests (including bacterial identification and AST) have been shown to facilitate faster optimization of antibiotic regimens and decrease hospital costs [14], with one study estimating the annual savings due to rapid AST in a 500-bed Illinois hospital at over \$6 million in 2019 dollars $[15,16]$. Without up-to-date estimates on the economic value of this technology, there is no clear return on investment to rapid AST implementation, which is a barrier to innovation and provider adoption.

\section{Materials and Methods}

We developed an economic valuation model with inputs based on peer-reviewed research in both the medical and economic literature for the savings provided by rapid AST relative to conventional AST.

\section{Operational basis of economic model}

If the initial antibiotic regimen given to a septic patient upon arrival to the hospital is effective against the infection, a reduction in lab time-to-result will not impact hospital length of stay. However, if the initial antibiotic is not effectively fighting the infection, the time-to-result of an antibiotic susceptibility test matters clinically. In the literature on antibiotic effectiveness, initially inappropriate antibiotic treatment (IIAT) cases are defined as instances in which a patient did not receive an antibiotic active against the culprit bacteria in the first 24 hours after a positive blood culture was drawn [17]. Implementation of rapid AST, which reduces time-toresult well below the 24-hour threshold, can therefore eliminate IIAT. Since IIAT has been shown to increase LOS (Table 1), we used the elimination of IIAT as a way to value the savings from reduced

\section{LOS due to rapid AST.}

Equation 1 outlines the basic model. Since rapid AST implementation can eliminate the incremental LOS due to IIAT, savings can therefore be estimated as the cost of a hospital bedday multiplied by the percentage of patients receiving IIAT and the incremental LOS (in days) due to IIAT.

Equation 1: Savings from Avoided IIAT = Cost of hospital bed * Proportion of septic patients receiving IIAT * LOS increase attributable to IIAT

To increase the accuracy of our estimate within this framework, we divided the sepsis population into four groups, stratifying by infection type and hospital bed location due to expected betweengroup differences in IIAT prevalence and hospital bed-day cost, respectively. The four groups were: Inpatient-Non-MDR, InpatientMDR, ICU-Non-MDR and ICU-MDR. For each of these groups, the savings number described in Equation 1 was scaled by the percentage of all sepsis patients which fell in that category. The total savings per patient was the sum of these weighted savings estimates over all four groups. Per-patient savings were translated into savings per 100,000 total hospital admissions by using an estimate of the proportion of all hospital admissions that were from sepsis as a scaling factor.

Each component of the model was compiled from a comprehensive literature search identifying key studies in the field and then combining individual estimates from these studies into a weighted average. Studies that were more recent, conducted in the US, had a large sample size, and demonstrated methodological rigor were weighted more heavily. This process was used to obtain estimates for the percentage of sepsis patients receiving IIAT as well as incremental LOS attributable to IIAT; separate estimates were calculated for MDR and non-MDR patients for these variables due to higher levels in MDR patients. Table 1 shows the studies used in this analysis with assigned weights. Given that SeLux can test more antibiotics than other rapid ASTs ("expanded antibiotic menu") and thus saves additional time for MDR infections by alleviating the need to run multiple sequential ASTs, we added one day of savings to the incremental LOS estimate for MDR groups. However, our sensitivity analysis pressure tests our assumptions to provide ranges of possible economic impact.

The same weighting methodology was used to obtain estimates for the other inputs to the model: hospital bed-day cost (Appendix Table 1), MDR prevalence in sepsis patients (Appendix Table 2), and prevalence of ICU admissions in sepsis patients (Appendix Table 3). The proportion of all hospitalizations due to sepsis also used this methodology (Table 2).

In addition to calculating the savings from our weighted input estimates, we also conducted sensitivity analyses to estimate the range of savings from rapid AST using all possible values of IIATrelated variables from the literature search in Table 1. 


\section{Results}

Our model found that replacing conventional AST with rapid AST for septic patients alone saves $\$ 1,642$ per septic patient (Table 3). This per-patient savings translates into $\$ 5.65$ million

Table 1: IIAT Percentage and Incremental LOS: Table of Included Studies

\begin{tabular}{|c|c|c|c|c|c|c|c|}
\hline $\begin{array}{l}\text { Authors } \\
\text { (Year) }\end{array}$ & Title (Journal) & $\begin{array}{c}\text { Country (Sample } \\
\text { Size) }\end{array}$ & $\begin{array}{l}\text { Study Population (MDR } \\
\text { Only?) * }\end{array}$ & $\begin{array}{l}\text { Incremental } \\
\text { LOS from IIAT } \\
\text { (days) }\end{array}$ & $\begin{array}{l}\text { Incremen- } \\
\text { tal LOS } \\
\text { Weight }\end{array}$ & IIAT \% & $\begin{array}{l}\text { IIAT \% } \\
\text { Weight }\end{array}$ \\
\hline $\begin{array}{l}\text { Shorr A et al } \\
\quad(2011)\end{array}$ & $\begin{array}{l}\text { Inappropriate antibiotic } \\
\text { therapy in Gram-negative } \\
\text { sepsis increases hospital } \\
\text { length of stay }\end{array}$ & USA (760) & $\begin{array}{c}\text { Adult patients with } \\
\text { severe sepsis due to } \\
\text { Gramnegative infection } \\
\text { (No) }\end{array}$ & 2 & 0.5 & $13.10 \%$ & 0.3 \\
\hline $\begin{array}{l}\text { Marschall J et } \\
\text { al (2008) }\end{array}$ & $\begin{array}{l}\text { Gram-negative bacteraemia } \\
\text { in non-ICU patients: factors } \\
\text { associated with inadequate } \\
\text { antibiotic therapy and } \\
\text { impact on outcomes (Journal } \\
\text { of Antimicrobial Chemo- } \\
\text { therapy) }\end{array}$ & USA (250) & $\begin{array}{l}\text { Gram-negative bacte- } \\
\text { remia ( } 92 \% \text { of sample } \\
\text { septic) (No) }\end{array}$ & 0 & 0.15 & $16.40 \%$ & 0.25 \\
\hline $\begin{array}{l}\text { Lee CC et al } \\
\quad(2012)\end{array}$ & $\begin{array}{l}\text { Impact of inappropriate } \\
\text { empirical antibiotic therapy } \\
\text { on outcome of bacteremic } \\
\text { adults visiting the ED (Amer- } \\
\text { ican Journal of Emergency } \\
\text { Medicine) }\end{array}$ & Taiwan (298) & $\begin{array}{l}\text { Bacteremic (blood } \\
\text { infection) adults with } \\
\text { sepsis (No) }\end{array}$ & 0 & 0.1 & $21.60 \%$ & 0.1 \\
\hline $\begin{array}{l}\text { Lee } S \text { et al } \\
\quad(2011)\end{array}$ & $\begin{array}{l}\text { Impact of discordant empir- } \\
\text { ical therapy on outcome of } \\
\text { community-acquired bacte- } \\
\text { remic acute pyelonephritis } \\
\text { (Journal of Infection) }\end{array}$ & $\begin{array}{l}\text { South Korea } \\
\text { (164) }\end{array}$ & $\begin{array}{l}\text { Patient with communi- } \\
\text { ty-acquired bacteremic } \\
\text { acute pyelonephritis } \\
\text { (No) }\end{array}$ & 5 & 0.1 & $21.50 \%$ & 0.1 \\
\hline $\begin{array}{c}\text { Gar- } \\
\text { nacho-Montero } \\
\text { et al (2003) }\end{array}$ & $\begin{array}{l}\text { Impact of adequate empiri- } \\
\text { cal antibiotic therapy on the } \\
\text { outcome of patients admit- } \\
\text { ted to the intensive care unit } \\
\text { with sepsis (Critical Care } \\
\text { Medicine) }\end{array}$ & Spain (406) & $\begin{array}{l}\text { Patients presenting } \\
\text { to the ICU with sepsis } \\
\text { (excludes ICU-acquired } \\
\text { sepsis) (No) }\end{array}$ & 0 & 0.1 & $17.00 \%$ & \\
\hline $\begin{array}{l}\text { Chen } \mathrm{H} \text { et al } \\
\text { (2013) }\end{array}$ & $\begin{array}{l}\text { Outcome of inadequate } \\
\text { empirical antibiotic therapy } \\
\text { in emergency department } \\
\text { patients with communityon- } \\
\text { set bloodstream infections } \\
\text { (Journal of Antimicrobial } \\
\text { Chemotherapy) }\end{array}$ & Taiwan (937) & Bacteremia (No) & 0 & 0.05 & $27.20 \%$ & 0.05 \\
\hline \multirow[t]{2}{*}{$\begin{array}{c}\text { Gonza- } \\
\text { lez-del-Castillo } \\
\text { Jet al (2017) }\end{array}$} & $\begin{array}{l}\text { Effect of the inadequacy of } \\
\text { antibiotic therapy in the } \\
\text { Emergency Department on } \\
\text { hospital stays (Enferme- } \\
\text { dades Infecciosas y Microbi- } \\
\text { ologia Clinica) }\end{array}$ & Spain (376) & $\begin{array}{l}\text { ED patients hospitalized } \\
\text { with any kind of infec- } \\
\text { tion (No) }\end{array}$ & N/A & N/A & $11.30 \%$ & 0.1 \\
\hline & & & $\begin{array}{l}\text { Weighted Average Esti- } \\
\text { mates (non-MDR) }\end{array}$ & 1.5 & & $16.50 \%$ & \\
\hline $\begin{array}{l}\text { Shorr A et al } \\
\quad(2008)\end{array}$ & $\begin{array}{l}\text { Inappropriate therapy for } \\
\text { methicillin-resistant Staph- } \\
\text { ylococcus aureus: Resource } \\
\text { utilization and cost implica- } \\
\text { tion (Critical Care Medicine) }\end{array}$ & USA (291) & $\begin{array}{l}\text { Patients with sterile-site } \\
\text { infection due to MRSA } \\
\text { (methicillin-resistant } \\
\text { staph aureus) (Yes) }\end{array}$ & 2 & 0.2 & $77.00 \%$ & 0.25 \\
\hline $\begin{array}{l}\text { Osih R et al } \\
\quad(2007)\end{array}$ & $\begin{array}{l}\text { Impact of Empiric Antibiotic } \\
\text { Therapy on Outcomes in } \\
\text { Patients with Pseudomonas } \\
\text { aeruginosa Bacteremia } \\
\text { (Antimicrobial Agents and } \\
\text { Chemotherapy) }\end{array}$ & USA (167) & $\begin{array}{c}\text { Pseudomonas bacter- } \\
\text { emia (Yes }\end{array}$ & 0 & 0.2 & $59.30 \%$ & 0.25 \\
\hline
\end{tabular}

per 100,000 total hospital admissions using a sepsis incidence of $3.44 \%$ of all hospital admissions (Table 2). The majority of savings came from MDR infection cases, which have a higher percentage of IIAT relative to non-MDR cases ( $64 \%$ vs. $17 \%$ ) as well as a longer incremental LOS due to IIAT (5.2 vs. 1.5) (Table 3). 


\begin{tabular}{|c|c|c|c|c|c|c|c|}
\hline $\begin{array}{l}\text { Lodise } \mathrm{T} \text { et al } \\
\qquad(2002)\end{array}$ & $\begin{array}{l}\text { Clinical Outcomes for } \\
\text { Patients with Bacteremia } \\
\text { Caused by Vancomycin-Re- } \\
\text { sistant Enterococcus in a } \\
\text { Level } 1 \text { Trauma Center (Clin- } \\
\text { ical Infectious Disease) }\end{array}$ & USA (106) & $\begin{array}{l}\text { Patients presenting with } \\
\text { enterococcal bacteremia } \\
\text { (Yes) }\end{array}$ & 7 & 0.2 & $77.40 \%$ & 0.25 \\
\hline $\begin{array}{l}\text { Lautenbach E } \\
\text { et al (2001) }\end{array}$ & $\begin{array}{l}\text { Extended-Spectrum b-Lacta- } \\
\text { mase-Producing Escher- } \\
\text { ichia coli and Klebsiella } \\
\text { pneumoniae: Risk Factors } \\
\text { for Infection and Impact of } \\
\text { Resistance on Outcomes } \\
\text { (Clinical Infectious Disease) }\end{array}$ & USA (99) & $\begin{array}{l}\text { E coli or Klebsiella pneu- } \\
\text { moniae patients (Yes) }\end{array}$ & 9 & 0.2 & N/A & $\mathrm{N} / \mathrm{A}$ \\
\hline $\begin{array}{l}\text { Kollef K et al } \\
\quad(2008)\end{array}$ & $\begin{array}{l}\text { Predictors of 30-Day Mor- } \\
\text { tality and Hospital Costs in } \\
\text { Patients With Ventilator-As- } \\
\text { sociated Pneumonia Attrib- } \\
\text { uted to Potentially Antibiot- } \\
\text { ic-Resistant Gram-Negative } \\
\text { Bacteria (Chest) }\end{array}$ & USA (76) & $\begin{array}{l}\text { Ventilator-associated } \\
\text { pneumonia patients } \\
\text { (Yes) }\end{array}$ & 0 & 0.05 & N/A & $\mathrm{N} / \mathrm{A}$ \\
\hline $\begin{array}{l}\text { Tumbarello M } \\
\text { et al (2010) }\end{array}$ & $\begin{array}{l}\text { Costs of Bloodstream Infec- } \\
\text { tions Caused by Escheri- } \\
\text { chia coli and Influence of } \\
\text { Extended-Spectrum-Beta- } \\
\text { Lactamase Production and } \\
\text { Inadequate Initial Antibiotic } \\
\text { Therapy (Antimicrobial } \\
\text { Agents and Chemotherapy) }\end{array}$ & Italy (134) & $\begin{array}{l}\text { E coli bloodstream infec- } \\
\text { tions (Yes) }\end{array}$ & 6 & 0.05 & $20.10 \%$ & 0.1 \\
\hline $\begin{array}{l}\text { Schwaber M et } \\
\text { al (2006) }\end{array}$ & $\begin{array}{l}\text { Clinical and Economic } \\
\text { Impact of Bacteremia with } \\
\text { Extended Spectrum--Be- } \\
\text { ta-Lactamase-Producing } \\
\text { Enterobacteriacea (Antimi- } \\
\text { crobial Agents and Chemo- } \\
\text { therapy) }\end{array}$ & Israel (198) & $\begin{array}{c}\text { E coli, Klebsiella } \\
\text { pneumoniae, or Proteus } \\
\text { bacteremia (Yes) }\end{array}$ & 6 & 0.05 & $65.70 \%$ & 0.1 \\
\hline \multirow[t]{2}{*}{$\begin{array}{l}\text { Falagas M et al } \\
\text { (2006) }\end{array}$} & $\begin{array}{l}\text { Comparison of mortality of } \\
\text { patients with Acinetobacter } \\
\text { baumannii bacteraemia } \\
\text { receiving appropriate and } \\
\text { inappropriate empirical } \\
\text { therapy (Journal of Antimi- } \\
\text { crobial Chemotherapy) }\end{array}$ & Greece (40) & $\begin{array}{c}\text { A baumannii bacteremia } \\
\text { (Yes) }\end{array}$ & 0 & 0.05 & $45.00 \%$ & 0.05 \\
\hline & & & $\begin{array}{l}\text { Weighted Average Esti- } \\
\text { mates (MDR) }\end{array}$ & $4.2^{* *}$ & & $64.30 \%$ & \\
\hline
\end{tabular}

${ }^{*}$ Note that separate IIAT \% and incremental LOS estimates were calculated for MDR patients and non-MDR patients, as both variables are higher for MDR patients.

**The MDR incremental LOS used in the model was 5.2 days (adding one day for additional savings for MDR patients due to SeLux's expanded antibiotic menu).

Table 2: Sepsis Proportion of Hospital Admissions: Table of Included Studies.

\begin{tabular}{|c|c|c|c|c|c|c|}
\hline Authors (Year) & $\begin{array}{c}\text { Publication Year (Data } \\
\text { Year) }\end{array}$ & Title (Journal) & Country (Sample Size) & Study Population & $\begin{array}{l}\text { Sepsis as Proportion } \\
\text { of All Hospital Admis- } \\
\text { sions* }\end{array}$ & Weight \\
\hline CDC (2007-10) & $2007-2010$ & $\begin{array}{l}\text { CDC National Hos- } \\
\text { pital Discharge } \\
\text { Surveys, 2007- } \\
2010 \text { (CDC) }\end{array}$ & USA (30-40 million) & $\begin{array}{l}\text { Discharges of } \\
\text { inpatients from } \\
\text { non-federal } \\
\text { hospitals }\end{array}$ & $5.00 \%$ & 0.2 \\
\hline Gaieski et al & 2013 (2004-2009) & $\begin{array}{l}\text { Benchmarking } \\
\text { the Incidence } \\
\text { and Mortality of } \\
\text { Severe Sepsis in } \\
\text { the United States } \\
\text { (Critical Care } \\
\text { Medicine) }\end{array}$ & USA (meta-analysis) & $\begin{array}{l}\text { Hospitalized } \\
\text { patients }\end{array}$ & $2.70 \%$ & 0.15 \\
\hline
\end{tabular}




\begin{tabular}{|c|c|c|c|c|c|c|}
\hline Stoller et al & $2016(2008-2012)$ & $\begin{array}{c}\text { Epidemiology of } \\
\text { Severe Sepsis: } \\
2008-2012 \\
\text { (Journal of Critical } \\
\text { Care) }\end{array}$ & USA (6.1 million) & $\begin{array}{l}\text { Hospitalized } \\
\text { patients }\end{array}$ & $3.90 \%$ & 0.15 \\
\hline Rhee et al & 2016 (2009-2014) & $\begin{array}{l}\text { Incidence and } \\
\text { Trends of Sepsis } \\
\text { in US Hospitals } \\
\text { Using Clinical } \\
\text { vs Claims Data, } \\
\text { 2009-2014 } \\
\text { (JAMA) }\end{array}$ & USA (2.9 million) & $\begin{array}{l}\text { Hospitalized } \\
\text { patients }\end{array}$ & $6.00 \%$ & 0.15 \\
\hline $\begin{array}{l}\text { Martin et al } \\
\quad(2003)\end{array}$ & 2003 (1979-2000) & $\begin{array}{l}\text { The Epidemiology } \\
\text { of Sepsis in the } \\
\text { United States from } \\
1979 \text { through } \\
2000 \text { (NEJM) }\end{array}$ & $\begin{array}{l}\text { USA (national NHDS } \\
\text { data) }\end{array}$ & NHDS data & $2.10 \%$ & 0.1 \\
\hline $\begin{array}{l}\text { Dombrovskiy } \\
\text { et al }\end{array}$ & 2007 (1993-2003) & $\begin{array}{l}\text { Rapid increase in } \\
\text { hospitalization } \\
\text { and mortality } \\
\text { rates for severe } \\
\text { sepsis in the } \\
\text { United States: A } \\
\text { trend analysis } \\
\text { from } 1993 \text { to } \\
2003 \text { (Critical } \\
\text { Care Medicine) }\end{array}$ & USA (8.4 million) & $\begin{array}{l}\text { Hospitalized } \\
\text { patients }\end{array}$ & $0.20 \%$ & 0.1 \\
\hline Paoli et al & $2018(2010-2016))$ & $\begin{array}{l}\text { Epidemiology and } \\
\text { Costs of Sepsis in } \\
\text { the United States- } \\
\text { An Analysis Based } \\
\text { on Timing of Diag- } \\
\text { nosis and Severity } \\
\text { Level (Critical } \\
\text { Care Medicine) }\end{array}$ & USA ( 2.5 million) & $\begin{array}{l}\text { Adults with } \\
\text { hospital d/c code } \\
\text { of sepsis }\end{array}$ & $1.10 \%$ & 0.1 \\
\hline \multirow[t]{2}{*}{$\begin{array}{l}\text { Angus et al } \\
\text { (2001) }\end{array}$} & 2001 (1995) & $\begin{array}{l}\text { Epidemiology } \\
\text { of severe sepsis } \\
\text { in the United } \\
\text { States: Analysis } \\
\text { of incidence, } \\
\text { outcome, and } \\
\text { associated costs of } \\
\text { care (Critical Care } \\
\text { Medicine) }\end{array}$ & USA (6.6 million) & $\begin{array}{l}\text { Discharges of } \\
\text { inpatients from } \\
\text { FL, MD, MA, NJ, } \\
\text { NY, VA, WA }\end{array}$ & $2.30 \%$ & 0.05 \\
\hline & & & & $\begin{array}{l}\text { Weighted Aver- } \\
\text { age Estimate }\end{array}$ & $3.44 \%$ & \\
\hline
\end{tabular}

*Note: Despite the clear upward trend of sepsis prevalence (increasing by 8.7-13.0\% per year as shown in Martin et al and Gaieski et al above, respectively), we did not inflate sepsis prevalence figures to 2019 .

Table 3: Length-of-Stay Savings from Rapid AST Implementation.

\begin{tabular}{|c|c|c|c|c|c|c|}
\hline Infection Type & Bed Type & $\begin{array}{c}\text { \% of Sepsis } \\
\text { Patients }\end{array}$ & Cost per Bed-Day & $\begin{array}{c}\text { \% of Patients Re- } \\
\text { ceiving IIAT }\end{array}$ & $\begin{array}{c}\text { Incremental LOS Days } \\
\text { Due to IIAT [1] }\end{array}$ & Savings \\
\hline Non-MDR & Inpatient & $32.94 \%$ & $\$ 2,405$ & $16.50 \%$ & 1.5 & $\$ 596$ \\
\hline MDR Inpatient & Inpatient & $3.17 \%$ & $\$ 2,405$ & $64.30 \%$ & 1.5 & $\$ 8,034$ \\
\hline Non-MDR & ICU & $58.28 \%$ & $\$ 3,586$ & $16.50 \%$ & 5.2 & $\$ 889$ \\
\hline MDR ICU & ICU & $5.61 \%$ & $\$ 3,586$ & $64.30 \%$ & & $\$ 11,982$ \\
\hline
\end{tabular}

Note:

1. One day added on to MDR patient savings estimate due to SeLux's expanded antibiotic menu.

2. The multiplier is 3,444 sepsis discharges per 100,000 total hospital discharges.

The range of incremental LOS due to IIAT was wide, from 0-5 1). Given this range, we ran sensitivity analyses to estimate savings days for non-MDR patients and 0-9 days for MDR patients (Table when changing the following inputs from minimum to maximum 
values from the literature as well as each 25th percentile: incremental LOS, proportion of patients with IIAT, or both variables (Figure 1). Estimates in this sensitivity analysis were directly from the literature as captured in Table 1 and not subject to any weighting. Changing incremental LOS inputs caused a wide range of savings, from $\$ 0.47$ to $\$ 12.91$ million. Different values of the proportion of patients with IIAT led to a smaller range of savings, from $\$ 2.68$ to $\$ 7.90$ million. When both variables were subject to change, the savings range spanned $\$ 0.19$ to $\$ 20.90$ million.

\section{Discussion}

Rapid AST technology offers many potential areas of benefit to hospital systems, including direct cost savings, patient benefits, and even assistance with antibiotic stewardship efforts. Our model, which only considers the direct cost impact of SeLux Rapid AST on hospital LOS in the sepsis patient population, estimates that implementation of rapid AST technology which successfully reduces the time-to-result over conventional AST methods could save hospitals $\$ 1,642$ per septic patient, or $7.3 \%$ of the over $\$ 22,000$ total cost per admission [18]. When scaled to the hospital level, this represents $\$ 5.65$ million saved per 100,000 total hospital admissions due to reduction in bed days. These savings are were derived using conservative estimates and are supported by savings of a similar magnitude found in Memorial Medical Center which found $\$ 6 \mathrm{M}$ in savings with fewer than 25,000 discharges $[15,16]$. These savings do not include all of the non-LOS benefits of rapid AST, including avoided antibiotic side effects, avoided antibiotic utilization spending by hospitals and reduced hospital acquired infections.

In addition, this estimate of $\$ 5.65 \mathrm{M}$ in savings per 100,000 discharges from SeLux rapid AST for septic patients alone is in line with previous estimates of total savings from rapid AST over all patients [14], possibly due to increased cost savings opportunities from the combination of rising sepsis incidence and decreased mortality in this population [19]. In a competitive healthcare climate where cost reduction is cited as a very high priority for $90 \%$ of US healthcare executives, this level of savings driven by rapid AST presents a strong value proposition for hospital systems to adopt rapid AST [20]. This technology meets the criteria of the triple aim, simultaneously 1) improving patient experience, 2) improving health, and 3) reducing costs, something rare in critical care [21]. From an even wider perspective, rising healthcare costs have been a major issue in the United States, which has spent a higher proportion of GDP on healthcare than any other OECD highincome country during the entire 21st century to date. In fact, US healthcare spending in 2016 was $17.1 \%$ of GDP, nearly double the $8.9 \%$ average healthcare expenditure of the 32 other highincome OECD countries [22]. These results provide evidence that investment in such technology not only has long-term strategic benefits, but also tangible, meaningful savings that can be realized soon after implementation.
While our model systematically analyzes one aspect of possible savings in sepsis patients, there are multiple areas other than direct cost savings in which rapid AST we project will offer additional benefits to patients and hospitals. For example, reductions in LOS and HAIs do not only benefit hospitals, but also clearly have an importantimpact on patient health. There are quality-of-life benefits associated with each day a patient spends out of the hospital or free of infection, which can be quantified using a quality-adjustedlife-year (QALY) approach and valued accordingly. In addition, the antibiotic stewardship benefits of narrowing antibiotic treatment earlier in a clinical course also adds to the total value of rapid AST. Moreover, the benefits of rapid AST are not limited to the sepsis patient population, but can extend to many other infectious disease admissions, such as UTIs, pneumonia, wound infections, or postsurgical infections. Future research in these areas would lead to a more complete estimate of rapid AST's total value.

\section{Conclusion}

Rapid AST presents a multifaceted value proposition for hospitals that rests on its ability to speed up the time-to-result for AST over conventional AST. In cases where rapid AST meets this requirement, it can provide hospitals with significant savings from reduced LOS primarily come from reduced LOS and a variety of other sources, such as reduced antibiotic usage, fewer antibiotic side effects, and a lower frequency of HAIs. We quantified savings from reduced LOS focusing exclusively on the sepsis patient population by creating an economic model with all inputs validated by peer-reviewed research. The magnitude of potential savings suggests that replacing conventional AST with rapid AST could provide a high return on investment for hospital systems.

\section{Acknowledgement}

None.

\section{Conflict of Interest}

The authors received some funding from SeLux Diagnostics to support this research.

\section{References}

1. Martin GS, David M Mannino, Stephanie Eaton, Marc Moss (2003) The Epidemiology of Sepsis in the United States from 1979 through 2000. N Engl J Med 348(16): 1546-1554.

2. Liu V, Escobar GJ, Greene JD, Jay Soule, Alan Whippy, et al. (2014) Hospital Deaths in Patients With Sepsis From 2 Independent Cohorts. JAMA 312(1): 90-92.

3. Paoli CJ, Mark A Reynolds, Meenal Sinha, Matthew Gitlin, Elliott Crouser (2018) Epidemiology and Costs of Sepsis in the United States-An Analysis Based on Timing of Diagnosis and Severity Level. Crit Care Med 46(12): 1889-1897.

4. CDC National Hospital Discharge Surveys (2007-2010) Centers for Disease Control and Prevention.

5. DF Gaeski, J Matthew Edwards, Michael J Kallan, Brendan G Carr (2013) Benchmarking the Incidence and Mortality of Severe Sepsis in the United States. Crit Care Med 41(5): 1167-1174. 
6. Levy MM, Evans LE, and Rhodes A (2018) Surviving Sepsis Campaign Bundle: 2018 Update. Intensive Care Med 44(6): 925-928.

7. Seymour CW, Foster Gesten, Hallie C Prescott, Marcus E Friedrich, Theodore J Iwashyna, et al. (2017) Time to Treatment and Mortality during Mandated Emergency Care for Sepsis. N Engl J Med 376: 22352244.

8. Severe Sepsis and Septic Shock Antibiotic Guide (2017) Stanford Health Stanford Antimicrobial Safety and Sustainability Program.

9. Kumar A (2009) Optimizing antimicrobial therapy in sepsis and septic shock. Critical Care Clinics 25(4): 733-751.

10. Flentie K, Benjamin R Spears, Felicia Chen, Nathan B Purmort, Kayla DaPonte, et al. (2019) Microplate-based surface area assay for rapid phenotypic antibiotic susceptibility testing. Sci Rep 9(1): 237.

11. Spears B, et al. (2019) Rapid, comprehensive-menu antimicrobial susceptibility testing directly from positive blood cultures. Poster presentation at ASM Microbe, USA.

12. Flentie K, et al. (2019) Rapid antimicrobial susceptibility testing with broad antibiotic menus using 384-well microplates." Poster presentation at ASM Microbe, USA.

13. Stern E, et al. (2018) Novel platform for rapid AST with expanded antibiotic menus." Oral presentation at ASM Microbe, USA. Atlanta, Georgia.

14. Galar A, J Leiva, M Espinosa, F Guillén Grima, S Hernáez, et al. (2012) Clinical and economic evaluation of the impact of rapid microbiological diagnostic testing. J Infect 65(4): 302-309.
15. Barenfanger J, Drake C, and Kacich G (1999) Clinical and Financial Benefits of Rapid Bacterial Identification and Antimicrobial Susceptibility Testing. J Clin Microbiol 37(5): 1415-1418.

16. Adjusted for inflation using CPI data from the BLS.

17. Shorr AF, Scott T Micek, Emily C Welch, Joshua A Doherty, Richard M Reichley, et al. (2011) Inappropriate antibiotic therapy in Gram-negative sepsis increases hospital length of stay. Crit Care Med 39(1): 46-51.

18. Moses MW, Paola Pedroza, Ranju Baral, Sabina Bloom, Jonathan Brown, et al. (2018) Funding and services needed to achieve universal health coverage: applications of global, regional, and national estimates of utilization of outpatient visits and inpatient admissions from 1990 to 2016, and unit costs from 1995 to 2016. The Lancet Public Health 4(1): E49-E73.

19. Stoller J, Laura Halpin, Matthew Weis, Brett Aplin, Weikai Qu, et al. (2016) Epidemiology of severe sepsis: 2008-2012. J Crit Care 31(1): 5862.

20. (2018) Survey: Success in a Transformative Environment Depends on Health Systems' Ability to Navigate Change. H2C Hammon Hanlon Comp LLC.

21. Stiefel M, Nolan K (2012) A Guide to Measuring the Triple Aim: Population Health, Experience of Care, and Per Capita Cost. Institute for Healthcare Improvement, IHI Innovation Series white paper, UK.

22. Authors' analysis of 2000-2016 OECD health expenditure by country. 